\title{
CHANGES AT MULTIPLE LEVELS OF THE HYPOTHALAMO-PITUITARY ADRENAL AXIS FOLLOWING REPEATED ELECTRICALLY INDUCED SEIZURES
}

\author{
Elizabeth A. Young, ${ }^{1}$ Robert L. Spencer, ${ }^{2}$ and Bruce S. McEwen ${ }^{2}$ \\ ${ }^{1}$ Mental Health Research Institute, University of Michigan, Ann Arbor, Michigan, and \\ ${ }^{2}$ Laboratory for Neuroendocrinology, Rockefeller University, New York City, New York, U.S.A.
}

(Recetued 6 March 1990; in final form 23 Apri 1990)

\begin{abstract}
SUMMARY
Seizures, including electrically induced seizures (ECS), activate the hypothalamo-pituitary-adrenal (HPA) axis in rats. The present studies were undertaken to characterize the effects of repeated ECS on hormone release and brain adrenal steroid receptors. Repeated ECS led to an increase in adrenal weight, an increase in the corticosterone response to the eighth seizure compared to the first seizure, and an increase in basal plasma corticosterone levels at the trough of the circadian rhythm. Despite increased plasma corticosterone levels at the time of sacrifice, there were no decreases in adrenal steroid receptor numbers in hypothalamus, cortex or hippocampus. In chronic ECS-treated rats which were adrenalectomized overnight to remove glucocorticoids, an increase in Type I (mineralocorticoid) steroid receptors occurred in both hippocampus and cortex. These data suggest that chronic ECS has a trophic effect on Type I receptors and that the higher levels of corticosterone resulting from chronic ECS do not induce adrenal steroid receptor down-regulation.
\end{abstract}

\section{INTRODUCTION}

ONE of the most replicated biological findings in psychiatry is the demonstration of abnormal HPA axis regulation in depression (Sachar et al., 1973; Carroll et al., 1976a; 1976b; 1981; Halbreich et al., 1985; Pfohl et al., 1985; Linkowski et al., 1987; Poland et al., 1987; Rubin et al., 1987). Although hypercortisolemia has not always been demonstrated, the failure to shut off cortisol secretion in response to dexamethasone has been demonstrated in a number of studies examining depressed subjects (Carroll et al., 1976a; 1976b; 1981; Pfohl et al., 1985; Poland et al., 1987). Most studies agree that the HPA axis normalizes following effective anti-depressant treatment (Holsboer et al., 1982; Greden et al., 1983). However, one of the most effective antidepressant treatments, electroconvulsive treatment (ECT), is itself a powerful stimulus to the HPA axis. Several studies have shown that ECT stimulates the release of ACTH from corticotrophs and that repeated ECT may affect the HPA axis (Allen et al., 1974; Alexopoulos et al., 1983; Aperia et al., 1984; Misiaszek et al., 1984; Weizman et al., 1987; Ghadirian et al., 1988).

Glucocorticoids such as corticosterone bind to two different receptors in brain, i.e. the glucocorticoid or Type II receptor and the mineralocorticoid or Type I receptor; these receptors may regulate different physiological functions (Reul \& de Kloet, 1985). They are collectively referred to as "adrenal steroid" receptors. The current study was undertaken in rats to characterize the effects

Correspondence to be addressed to: Dr. Elizabeth A. Young, Mental Health Research Institute, 205 Washtenaw Place, Ann Arbor, MI 48109-0720, USA. 
of repeated electrically induced seizures (ECS) on corticotroph and adrenal responses, and whether ECS affects brain adrenal steroid receptors.

\section{METHODS}

Male Sprague Dawley rats were obtained from Charles River (Portage, MI) and housed in groups (five to six per cage) in a controlled environment on a 12-hr light-dark schedule (lights on at $0700 \mathrm{~h}$ ). ECS was administered in the morning between $0830 \mathrm{~h}$ and $1030 \mathrm{~h}$ by delivery of a brief electrical pulse $(70 \mathrm{mAmp}, 0.15 \mathrm{sec}, 60 \mathrm{~Hz}$ ) via ear clip electrodes. Rats were held in the investigator's hand for the duration of the seizure, approximately $30 \mathrm{sec}$. For chronic studies, the rats were returned to their home cage following the termination of the seizure. Unless otherwise indicated, for acute studies, animals were decapitated 3-5 min after the convulsive stimulus. For chronic studies, rats received daily ECS for eight days and were decapitated $24 \mathrm{hr}$ following their last treatment, except where further indicated. Animals were decapitated in the immediately adjacent room within $30 \mathrm{sec}$ of removal from their home cage. Trunk blood for hormonal assays was obtained at the time of decapitation.

To assess corticotroph release into plasma following seizure, a radioimmunoassay (RIA) for $\beta$-endorphin was used. $\beta$-endorphin and ACTH are synthesized as part of the same precursor, proopiomelanocortin, which is processed within secretory granules to yield equimolar amounts of ACTH and $\beta$-endorphin/ $\beta$-lipotropin. Prior to RIA, plasma samples were extracted with a Sep-Pak (Waters, Milford, MA) extraction procedure (Cahill et al., 1983). The $\beta$-endorphin antibody was a gift of Huda Akil. It was used at a final dilution of $1: 40,000$ as described previously (Cahill et al., 1983). The assay buffer was $150 \mathrm{mM}$ phosphate, $\mathrm{pH} 8.2$, with $0.1 \%$ bovine serum albumin (Fraction V, RIA grade, Sigma, St. Louis, MO). [ $\left.{ }^{125} \mathrm{I}\right] \beta$-endorphin ${ }_{1-31}$ was used as the radiolabelled tracer, and $\beta$ endorphin $_{1-31}$ for the unlabelled standard. The samples and standards were dissolved in $0.1 \%$ human serum albumin (HSA, Fraction V, Sigma, St. Louis, MO), pH 3.0 with $1 \mathrm{~N} \mathrm{HCl}$. The equivalent of 0.25 ml plasma was added per assay tube.

The ACTH antibody also was a gift of Huda Akil. The antibody was used at a final titer of 1:80,000. The assay buffer was $150 \mathrm{mM}$ phosphate, $\mathrm{pH} 7.4$, with $50 \mathrm{mM} \mathrm{NaCl}$, and $0.1 \%$ polylysine. The samples and standards were dissolved in $0.1 \%$ human serum albumin, $\mathrm{pH} 3.0$ with $1 \mathrm{~N} \mathrm{HCl}$. [125 $\mathrm{I}$ ACTH 1 -39 was used as the radiolabelled tracer, and $\mathrm{ACTH}_{1-39}$ was used for the unlabelled standard: The equivalent of $0.5 \mathrm{ml}$ rat plasma was added per assay tube.

Corticosterone was assayed with a competitive protein binding (CBG) assay. $\left[{ }^{3} \mathrm{H}\right]$ corticosterone was used as the radiolabelled ligand, and corticosterone as the unlabelled standard. Samples were extracted with Sep-Pak, followed by an ethanol-saline extraction prior to assay. Fuller's earth was used as the absorbant to separate bound from free ligand.

For adrenal steroid receptor assays, animals were adrenalectomized $16 \mathrm{hr}$ before morning sacrifice. The adrenalectomies were done under Metofane anesthesia with a dorsal surgical approach. Animals were observed until they were fully awake and then were returned to their home cages. They were given $0.9 \%$ saline overnight in place of water. Following sacrifice by decapitation, the brains were rapidly removed and dissected into the following brain regions: hypothalamus, hippocampus and parietal cortex adjacent to the hippocampus. These regions were frozen on dry ice and stored at $-80^{\circ} \mathrm{C}$.

On the day of the glucocorticoid binding assay, the frozen brain regions were homogenized with 15 strokes of a hand held homogenizer in $10 \mathrm{mM}$ ice cold Tris buffer, $\mathrm{pH} 7.4$, with $1 \mathrm{mM}$ EDTA, $10 \%$ glycerol, $20 \mathrm{mM}$ molybdate and $1 \mathrm{mM}$ dithiothreitol. The homogenates were centrifuged at $40,000 \mathrm{RPM}$ in a Ti-50 rotor $(145,000 \mathrm{~g})$ in a Beckman ultracentrifuge for $30 \mathrm{~min}$. The supernatant (cytosol) was transferred to another tube and kept on ice until use. For estimates of within-group variability and treatment effects, a single-point assay was conducted for the three brain regions in individual animals. This assay used a saturating concentration $(10 \mathrm{nM})$ of $\left.{ }^{3} \mathrm{H}\right]$ dexamethasone (Amersham, Arlington Heights, IL, specific activity $=70-97 \mathrm{Ci} / \mathrm{mmol}$ ). Type II (glucocorticoid, GR) binding is defined as the portion of binding displaced by 500nM RU 26988, a selective Type II ligand (Moguilewsky \& Raynaud, 1980). Type I (mineralocorticoid, MR) binding is defined as the portion of binding not displaced by RU 26988 but displaced by $2.5 \mu \mathrm{M}$ corticosterone. The samples were incubated overnight at $4^{\circ} \mathrm{C}$, and bound ligand was separated from free with $1 \mathrm{ml}$ Sephadex LH-20 minicolumns. The eluate from the column was collected directly into scintillation vials, scintillation cocktail was added, and the samples were counted in a Packard scintillation counter. All samples were run in triplicate, and the triplicates averaged to calculate fmol bound. A portion of the original cytosol was saved and assayed for protein content by the Bio Rad protein assay. The values are expressed as fmol bound/mg protein. In addition to single point estimates of $B_{\max }$, hippocampal and cortical tissue from each rat per treatment group was pooled for Scatchard plot estimates of $\mathbf{K}_{\mathbf{D}}$ between groups. The pooled homogenates were processed identically to the single point samples. Aliquots were incubated with five concentrations of $\left[{ }^{3} \mathrm{H}\right]$ dexamethasone between $0.3 \mathrm{nM}$ and $10 \mathrm{nM}$. Type I and Type II binding were defined and quantitated for each concentration of $\left[{ }^{3} \mathrm{H}\right]$ dexamethasone, as described above. 
RESULTS

ECS resulted in a prompt rise in plasma ACTH and $\beta$-endorphin in rats at 3-5 min, supporting parallel release of these two hormones with ECS. The mean data for three experiments are shown in Fig. 1 (Student's $t$ test, $p=0.001, p=0.0027$ and $p=0.001$ for each experiment).

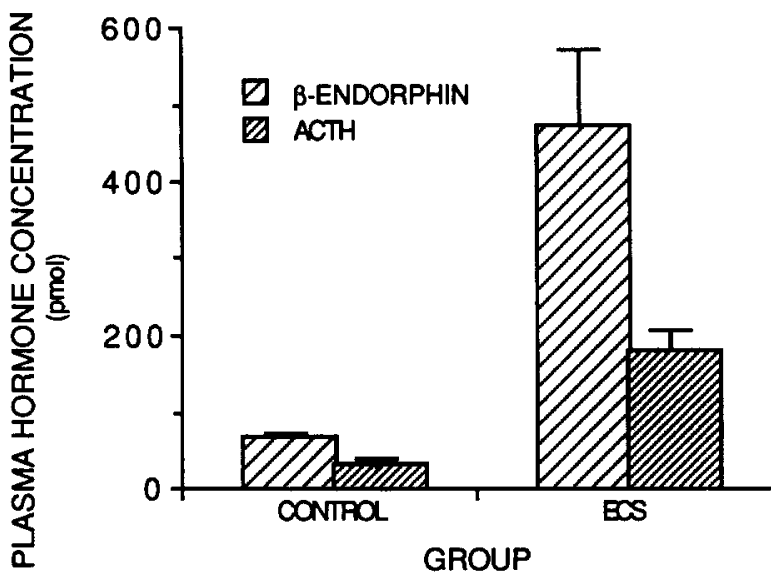

ACTH and $\beta$-Endorphin Response to Acute ECS

FIG. 1: Plasma ACTH and $\beta$-endorphin response to acute ECS $5 \mathrm{~min}$ following the onset of seizure. The data are the mean of three experiments. For each experiment there were six to 10 rats per group (total 22 rats per group).

A time course of the release of $\beta$-endorphin and corticosterone into plasma was compared between the first and eighth ECS sessions and is shown in Figs. 2 and 3. Although the initial $\beta$ endorphin response appears to be greater on the eighth session than the first session, there was no difference in the $\beta$-endorphin response to the first or eighth ECS session (F=2.37, $p=$ NS, two-way ANOVA for 0-60 min; F=2.8, $p=\mathrm{NS}$, two-way ANOVA for 0-5 min). In contrast, there was a significant difference in the glucocorticoid response to the first and eighth ECS (two-way ANOVA: $\mathrm{F}=21.8, p=0.0001$ for acute response to $\mathrm{ECS} ; \mathrm{F}=12.2, p=0.0008$ for repeated treatment; no significant interactions). As evident in Fig. 3, chronic ECS led to an increase in basal steroid levels. This was replicated in two additional experiments (Student's $t$ test $p=0.001$ and $p=0.03$ ). The discrepancy between corticotroph secretion as reflected in $\beta$-endorphin response and adrenal response as reflected in corticosterone levels may be explained by adrenal hypertrophy: There was a significant increase in adrenal weight in the chronic ECS rats (control $=11.4 \pm 0.57 \mathrm{mg} / 100 \mathrm{~g}$ BW; chronic ECS $=14.7 \pm 1.1 \mathrm{mg} / 100 \mathrm{~g} \mathrm{BW}, p=0.02$, Student's $t$ test; uncorrected for BW, control adrenals $=39.6 \pm 2.6 \mathrm{mg}$, chronic ECS adrenal $=40.3 \pm 2.8 \mathrm{mg}$ ).

To measure Type I and Type II adrenal steroid binding, groups of control and ECS rats were adrenalectomized $16 \mathrm{hr}$ before decapitation (seven rats per group). Glucocorticoid binding was measured in the hypothalamus, hippocampus and cortex. There was no difference observed between control and ECS rats in Type II binding in any brain region $(\mathrm{F}=1.4, p=\mathrm{NS})$. There was a small number of Type I receptors in the cortex and a larger number of receptors in the hippocampus; these were increased in the chronic ECS rats $(\mathrm{F}=6, p=0.02$, two-way ANOVA). There was a very small but detectable number of Type I receptors in the hypothalamus; the number was so 


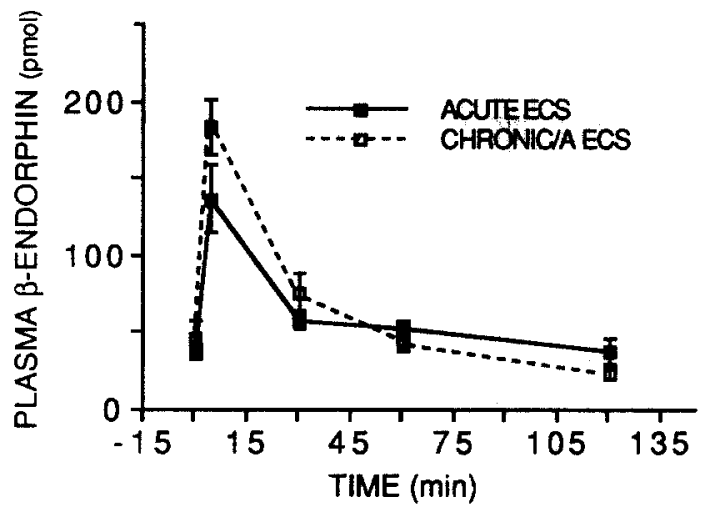

Time Course ECS

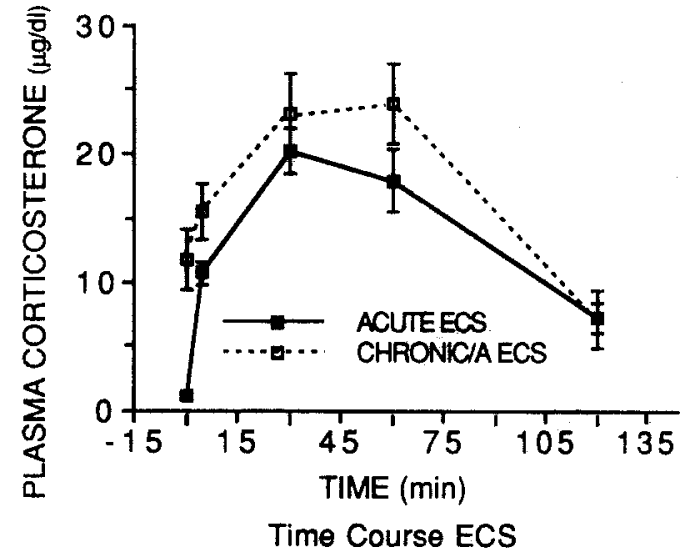

Fic. 2 (above, left): Comparison of plasma B-endorphin response to the first and eighth ECS. The graphs show the mean and SEM data for seven rats/group at each time point.

Fic. 3 (above, right): Comparieon of corticosterone response to the first and eighth ECS from 0-120 min. The graphs present the mean and SkM data for seven rats/group at each time point.

small (less than $20 \%$ of cortex) that quantitative estimates were unreliable. A repeat experiment in which rats were adrenalectomized $20 \mathrm{hr}$ before sacrifice demonstrated a similar increase in Type I receptors in the hippocampus ( $\mathrm{F}=4.8, p<0.05$, two-way ANOVA), with no change in Type II receptors in hypothalamus, hippocampus or cortex $(F=.35, p=N S$, two-way ANOVA, seven rats per group). Consequently, these data demonstrate an increase in the number of Type I adrenal steroid receptors, with no change in Type II receptors, following chronic ECS. The mean data for the two experiments are shown in the Table. Scatchard plots of pooled control and ECS rats demonstrated similar $K_{D} s$ for the Type I receptor in hippocampus between groups (mean of two experiments: $K_{D}=2.4 \mathrm{nM}$ for control and $1.2 \mathrm{nM}$ for $\mathrm{ECS} ; \mathrm{B}_{\max }=27 \mathrm{fmol} / \mathrm{mg}$ protein for control and $33 \mathrm{fmol} / \mathrm{mg}$ protein for ECS), confirming that the increase in binding was due to an increase in receptor number in the chronic ECS rats.

EFFECT OF CHRONIC ECS ON TYPE I AND TYPE II GLUCOCORTICOID RECEPTORS

\section{Single-point estimates}

\begin{tabular}{rcc} 
Hypothalamus II & $74.3 \pm 9.9$ & $74.8 \pm 8.5$ \\
Hippocampus I & $26.8 \pm 5.3$ & $41.8 \pm 5.6$ \\
II & $124 \pm 11.5$ & $114 \pm 11.5$ \\
Cortex I & $7.4 \pm 1.5$ & $10 \pm 1$ \\
II & $125 \pm 5$ & $110 \pm 5$ \\
& Scatchard Data & \\
Hippocampus & & \\
K $_{\text {D I }}$ & 2.4 & 1.2 \\
II & 0.6 & 0.55 \\
B $_{\text {max I }}$ & 27 & 33 \\
II & 125 & 129 \\
\hline Mean (土SEMs) of two experments (13 rats per group).
\end{tabular}


To confirm the lack of effect of elevated plasma corticosterone on Type II receptors, adrenal steroid receptor binding in brain was also evaluated in intact (non-adrenalectomized) rats. Since the Type I receptor is bound extensively by endogenous hormone even under non-stress conditions, in intact rats the majority of the adrenal steroid binding represents Type II (glucocorticoid) receptor binding, (Reul \& de Kloet, 1985; Spencer et al., 1990). In these intact rats, only total binding $\left(10 \mathrm{nM}\left[{ }^{3} \mathrm{H}\right]-\right.$ dexamethasone minus excess corticosterone) was measured. Animals were sacrificed $24 \mathrm{hr}$ following the seventh ECS session (seven rats per group). As expected, basal corticosterone levels in the chronic $E C S$ rats were significantly increased at the time of decapitation (control vs. ECS, $p=0.029$, unpaired two-tailed $t$-test) (Fig. 4). There was no significant effect of treatment on receptor number for the ECS rats in hypothalamus, cortex or hippocampus. This confirms the adrenalectomy data demonstrating no decrease in Type II receptor binding despite ele-

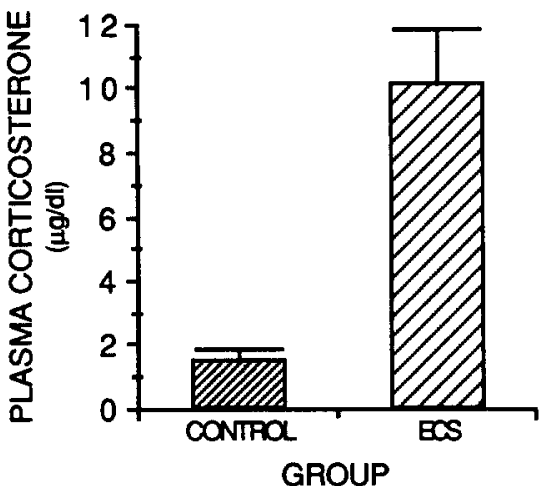

Basal Steroid Levels Following Chronic ECS

Fig. 4: Comparison of baseline corticosterone levels in natve, unhandled rats (control) or rats which recelved dally ECS for seven days. The mean data from two experiments are shown. Corticosterone samples were obtained in the morning at the nadir of the rat circadian rhythm (controll, and $24 \mathrm{hr}$ following the seventh ECS. vated plasma glucocorticoid levels.

\section{DISCUSSION}

Electrically induced seizures can act as a stimulus to the HPA axis. Several studies have indicated that ECT releases ACTH; the effect of repeated ECT on the corticotroph response is more controversial (Allen et al., 1974; Alexopoulos et al., 1983; Weizman et al., 1987; Herman et al., 1989a). Herman et al. (1989a) demonstrated in rats an increase in corticotropin releasing hormone messenger RNA (CRH mRNA) in the paraventricular nucleus (PVN) of hypothalamus following seven daily ECS sessions. This increase in CRH mRNA was accompanied by a decrease in CRH content, suggesting an increased release of CRH into hypophyseal portal blood with repeated ECS. This increased CRH drive resulted in an increase in ACTH and $\beta$-endorphin content of anterior lobe corticotrophs, presumably because of the increase in CRH-driven POMC biosynthesis and processing. An increase in the ACTH and $\beta$-endorphin content in anterior lobe corticotrophs was also observed in the current experiments (data not shown). This increased content was not accompanied by increased $\beta$-endorphin release with repeated seizures. These data are in agreement with previously published data on repeated footshock stress, which demonstrated a two-fold increase in anterior lobe ACTH and $\beta$-endorphin peptide content, but a similar release of ACTH and $\beta$-endorphin with the first and 15th footshock stress (Young \& Akil, 1985). However, repeated ECS did result in increased corticosterone levels, both at rest and following the eighth seizure. This failure to detect increased corticotroph secretion, as reflected by $\beta$-endorphin measures, despite evidence of increased adrenal corticosterone secretion, may be explained by adrenal hypertrophy, with resulting increased sensitivity to ACTH. In addition, the elevated resting corticosterone levels may act through intermediate feedback to inhibit corticotroph secretion in response to seizures. Thus, the elevated glucocorticoid plasma levels may result in changes in feedback signals to the HPA axis, as communicated through adrenal steroid receptors.

The demonstration of normal numbers of adrenal steroid receptors in the face of elevated 
steroid levels is unexpected. The measurements of Type I and Type II receptors in overnight adrenalectomized rats demonstrated an increase in Type I adrenal steroid receptors following chronic ECS. The data from intact rats confirm the lack of down-regulation of Type II receptors in chronic ECS rats. These results indicate that the hypersecretion of glucocorticoids resulting from ECS treatment is not sufficient to produce a down-regulation of hippocampal adrenal steroid receptors. These data are in apparent disagreement with the data of Sapolsky et al. (1984), who demonstrated that chronic stress and glucocorticoid administration down-regulate adrenal steroid receptors in the hippocampus. This difference may be secondary to differences in the stressors and the length of time that glucocorticoids are elevated, or to the absolute levels of corticosterone achieved. It suggests that seizures have widespread effects on neuronal functioning apart from their activation of the HPA axis, and they may stimulate a factor that has a trophic effect on adrenal steroid receptors. Data from chronic ethanol-treated rats also demonstrated that the elevated glucocorticoid secretion following daily ethanol administration did not lead to down-regulation of adrenal steroid receptors (Spencer \& McEwen, 1990). In one of two experiments an increase in Type I receptors also was observed. Again, ethanol may have other generalized neuronal effects that counteract the elevated glucocorticoid levels.

An alternate explanation may involve regulation of Type I receptors by Type II receptor occupancy. Reul et al. (1989) demonstrated an increase in Type I binding in adrenalectomized rats given dexamethasone chronically in their drinking water and hypothesized that either the efficiency of translation of Type I mRNA or the stability of the Type I protein was affected by Type II receptor occupancy. However, dexamethasone is a synthetic steroid that occupies Type II receptors, with little occupation of Type I receptors in vivo. In contrast, corticosterone, the natural steroid, should occupy both Type I and Type II receptors in vivo. Consequently, it is unclear whether this possible modulation by Type II receptors is sufficient to overcome the expected effects of occupancy of Type I receptors by corticosterone.

The physiological significance of this observed increase in Type I receptors in the hippocampus is unclear. The hippocampus has long been regarded as an inhibitory input to the HPA axis (cf. Sapolsky, 1986 for review). Herman et al. (1989b) demonstrated that removal of the hippocampus leads to increased CRH mRNA in the PVN as well as an induction of arginine vasopressin mRNA (AVP, another ACTH secretagogue) in the CRH neurons. This increase in CRH and AVP mRNA occurs despite the significantly elevated plasma ACTH and corticosterone levels in these hippocampectomized rats. Although different regions of the hippocampus may have different effects on the HPA axis, these experiments point out the importance of the trans-synaptic inhibitory input from the hippocampus to the PVN to inhibit CRH and subsequent ACTH secretion. However, whether this inhibitory input acts through occupation of Type I or Type II adrenal steroid receptors in the hippocampus has not yet been determined. In a study utilizing the administration of specific Type I and Type II receptor antagonists in vivo, blockade of both receptor types extended the duration of the corticosterone response to acute stress (Ratka et al., 1989). de Kloet et al. (1988) demonstrated that local injection of RU 38486 (a Type II antagonist) into the dentate gyrus of the hippocampus did not initiate an HPA axis response, although it was able to affect behavioral responses, whereas Injection of RU 38486 into the PVN did result in HPA axis disinhibition. These data suggest that Type II receptors in the dentate gyrus are not involved in the inhibitory influence of the hippocampus on HPA axis function. Although it is not yet possible to delineate the roles of both the Type I and Type II receptors in feedback regulation in vivo, there also are studies that suggest both positive and negative feedback effects of glucocorticoids can occur in vivo (James et al., 1965; Jones et al., 1972; 1974; Krieger et al., 1975; Fehn et al., 1977; 1979; Mahmoud et al., 1984; Young \& Akil, 1988). A possible positive feedback effect of glucocorticoids on their own release would be consistent with the effects we have observed in the rats 
receiving chronic ECS, i.e. both increased Type I receptors and increased basal plasma corticosterone levels.

In conclusion, repeated ECS led to an up-regulation of some elements of the HPA axis, particularly CRH secretion, ACTH corticotroph content and adrenal steroid levels. The increase in adrenal steroid levels did not lead to the expected decrease in adrenal steroid receptors in brain; in fact, Type I adrenal steroid receptors were significantly elevated. The relationship between increased plasma glucocorticoid levels and increased adrenal steroid receptors in brain remains to be elucidated. It is possible that the increased adrenal steroid receptor numbers are secondary to a more generalized effect of seizures than stimulation of the HPA axis. Whether the observed changes in adrenal steroid receptors following repeated seizures play any role in the normalization of the DST in man following successful treatment with ECT is unknown.

Acknowledgements: Supported by NIMH grants of MH00427, MH422251 and MH41256.

\section{REFERENCES}

Alexopoulos GS, Inturrisi CE, Lipman R, Frances R, Haycox J, Dougherty JH, Rossier J (1983) Plasma immunoreactive $\beta$-endorphin levels in depression. Arch Gen Psychiatry 40: 181-183.

Allen MJP, Denney D, Kendall JW, Blachly PH (1974) Corticotropin release during ECT in man. Am J Psychiatry 131: $1225-1228$.

Aperia B, Thoren M, Zettergren M, Wetterberg L (1984) Plasma pattern of adrenocorticotropin and cortisol during electroconvulsive therapy in patients with major depressive illness. Acta Psychiatr Scand 70: 361 -369.

Cahill CA, Matthews JD, Akil H (1983) Human plasma $\beta$-endorphin-like peptides: a rapid, high recovery extraction technique and validation of radioimmunoassay. J Clin Endocrinol Metab 56: 992 -997.

Carroll BJ, Curtis GC, Mendels J (1976a) Neuroendocrine regulation in depression I. Limbic system-adrenocortical dysfunction. Arch Gen Psychiatry 33: 1039-1044.

Carroll BJ, Curtis GC, Mendels J (1976b) Neuroendocrine regulation in depression II. Discrimination of depressed from non-depressed subjects. Arch Gen Psychiatry 33: 1051-1058.

Carroll BJ, Feinberg M, Greden JF, Tarika J, Albala AA, Haskett RF, James NM, Kronfol Z, Lohr N, Steiner M, de Vigne JP, Young EA (1981) A specific laboratory test for the diagnosis of melancholia: standardization, validation and clinical utility. Arch Gen Psychiatry 38: 15-22.

de Kloet R, De Kock S, Schild V, Veldhuis HD (1988) Antiglucocorticoid RU 38486 attenuates retention of a behavior and disinhibits the hypothalamic-pituitary adrenal axis at different brain sites. Neuroendocrinology 47: $109-115$.

Fehm FL, Voight KH, Lang RE, Beinert KE, Kummer GW, Pfeiffer OF (1977) Paradoxical ACTH response to glucocorticoid in Cushing's disease. N Engl J Med 297: 904-907.

Fehm FL, Voight KH, Kummer K, Lang R, Pfeiffer OF (1979) Positive rate sensitive corticosteroid feedback mechanism of ACTH secretion in Cushing's disease. J Clin Invest 64: 102-108.

Ghadirian AM, Gianoulakis C, Nair NPV (1988) The effects of electroconvulsive therapy on endorphins in depression. Biol Psychiatry 23: 459-464.

Greden JF, Gardener R, King D, Grunhaus L, Carroll BJ, Kronfol Z (1983) Dexamethasone suppression test in antidepressant treatment of melancholia-the process of normalization and test-retest reproducibility. Arch Gen Psychiatry 40: 493-500.

Halbreich U, Asnis GM, Schindledecker R, Zumoff B, Nathan RS (1985) Cortisol secretion in endogenous depression I. Basal plasma levels. Arch Gen Psychiatry 42: 909-914.

Herman JP, Schafer MK, Sladek C, Day R, Young EA, Akil H, Watson SJ (1989a) Chronic electroconvulsive shock treatment elicits up-regulation of CRF and AVP mRNA in select populations of neuroendocrine neurons. Brain Res 501: 235-246.

Herman JP, Schafer MK-H, Young EA, Thompson RC, Douglass JO, Akil H, Watson SJ (1989b) Hippocampal regulation of the hypothalamo-pituitary-adrenocortical axis: in situ hybridization analysis of CRF and vasopressin messenger RNA expression in the hypothalamic paraventricular nucleus following hippocampectomy. $J$ Neurosci 9: 3072-3082.

Holsboer F, Liebl R, Hofschuster E (1982) Repeated dexamethasone suppression test during depressive illness. Normalization of test result compared with clinical improvement. J Affect Disord 10: 241-249.

James VHT, Landon J, Wynn V (1965) Oral and intravenous suppression tests in the diagnosis of Cushing's Syndrome. J Endocrinol 33: 515-542. 
Jones MT, Brush FR, Neame RLB (1972) Characteristics of fast feedback control of corticotrophin release by corticosteroids. J Endocrinol 55: $489-497$.

Jones MT, Tiptaft EM, Brush, FR, Fergusson DAN, Neame RLB (1974) Evidence for dual corticosterone receptor mechanism in the control of adrenocorticotropin secretion. J Endocrinol 60:223-233.

Krieger DT, Amorosco L, Linick F (1975) Cyproheptadine induced remission of Cushing's disease. New Engl J Med 293: 893-896.

Linkowski P, Mendelwicz J, Kerkhofs M, Le Clencq R, Goldstein J, Brasseur M, Copinschi G, van Cauter E (1987) 24 hour profiles of ACTH, cortisol and growth hormone in major depressive illness: effect of antidepressant treatment. J Clin Endocrinol Metab 65: 141-152.

Mahmoud SN, Scaccianoce S, Scraggs PR, Nicholson SA, Gillham B, Jones MT (1984) Characteristics of corticosteroid inhibition of adrenocorticotropin release from the anterior pituitary gland of the rat. $J$ Endocrinol 102: 33-42.

Misiaszek J, Cork RC, Hameroff SR, Finley J, Weiss JL (1984) The effects of electroconvulsive therapy on plasma B-endorphin. Biol Psychiatry 19: 451-455.

Moguilewsky M, Raynaud JP (1980) Evidence for a specific mineralocorticoid receptor in rat pituitary and brain. J Steroid Biochem 12: $309-314$.

Pfohl B, Sherman B, Schlechte J, Stone R (1985) Pituitary/adrenal axis rhythm disturbances in psychiatric patients. Arch Gen Psychiatry 42: 897-903.

Poland RE, Rubin RT, Lesser IM, Lane LA, Hart PJ (1987) Neuroendocrine aspects of primary endogenous depression II. Serum dexamethasone concentrations and hypothalamic pituitary adrenal activity as determinants of the dexamethasone suppression test response. Arch Gen Psychiatry 44: 790-795.

Ratka A, Sutanto W, Bloemers M, de Kloet ER (1989) On the role of mineralocorticoid (Type I) and glucocorticoid (Type II) receptors in neuroendocrine regulation. Neuroendocrinology 50: 117-123.

Reul JMHM, de Kloet ER (1985) Two receptor systems for corticosterone in rat brain: microdissection and differential occupation. Endocrinology 117: 2505-2511.

Reul JMHM, Pearce PT, Funder JW, Krozowski ZS (1989) Type I and Type II corticosteroid receptor gene expression in the rat: effect of adrenalectomy and dexamethasone administration. Mole Endocrinol 3: 1674-1680.

Rubin RT, Poland RE, Lesser IM, Winston RA, Blodgett ALN (1987) Neuroendocrine aspects of primary endogenous depression I. Cortisol secretory dynamics in patients and matched controls. Arch Gen Psychiatry 44: $328-336$.

Sachar EJ, Hellman L, Roffwarg HP, Halpern FS, Fukushima DK, Gallagher TF (1973) Disrupted 24 hour patterns of cortisol secretion in psychotic depressives. Arch Gen Psychiatry 28: 19-24.

Sapolsky RM, Krey LC, McEwen BS (1984) Stress down-regulates corticosterone receptors in a site-specific manner in the brain. Endocrinology 114: 287-292.

Sapolsky RM, Krey LC, McEwen BS (1986) The neuroendocrinology of stress and aging: the glucocorticoid cascade hypothesis. Endocr Rev 7: 284-301.

Spencer RL, McEwen BS (1990) Adaptation of the hypothalamo-pituitary-adrenal axis to chronic ethanol stress. Neuroendocrinology, in press.

Spencer RL, Young EA, Choo PH, McEwen BS (1990) Adrenal steroid type I and type II receptor binding: estimates of in vivo receptor number, occupancy and activation with varying level of steroid. Brain Res 514 : 317-348

Weizman A, Gil-Ad I, Grupper D, Tyano S, Laron Z (1987) The effects of acute and repeated electroconvulsive treatment on plasma $\beta$-endorphin, growth hormone, prolactin, and cortisol secretion in depressed patients. Psychopharmacology 93: $122-126$.

Young EA, Akil H (1985) CRF stimulation of ACTH/B-endorphin release: effect of acute and chronic stress. Endocrinology 117: 23-30.

Young EA, Akil H (1988) Paradoxical effects of corticosteroids on pituitary ACTH/b-endorphin release in stressed rats. Psychoneuroendocrinology 13: 317-323. 